Original Paper http://ajol.info/index.php/ijbcs http://indexmedicus.afro.who.int

\title{
Insertion/deletion gene variants of angiotensin converting enzyme do not predispose cameroonians of the Bantu ethnic group to essential hypertension
}

\author{
Stephen Mbigha GHOGOMU*, Marie Ngejang TAMUTAN \\ and Johnston Isaac Mboni MUSONG \\ Department of Biochemistry and Molecular Biology, Molecular and Cell Biology Laboratory, \\ Biotechnology Unit, Faculty of Science, University of Buea, Cameroon. \\ *Corresponding author; E-mail: stephen.ghogomu@ubuea.cm \\ Tel: +(237) 6784556 46; Fax: +(237) $33322272 / 33432508$
}

\section{ACKNOWLEDGMENTS}

This research work received financial support from the Cameroon Ministry of Higher Education in the form of research modernization allowance as well as from the 'Academie de Recherche et d'Enseignement Superieur - Commission de la Cooperation au Development' (ARES-CCD), Belgium in the form of laboratory equipment to the Molecular and Cell Biology Laboratory of the Biotechnology Unit.

\begin{abstract}
The insertion/deletion (I/D) polymorphism in the angiotensin-converting enzyme gene has been reported to be implicated in the predisposition to essential hypertension (EH). This association may depend on ethnic and genetic backgrounds. The objective of this study was to determine if the possible I/D polymorphism in the Bantu ethnic group of Cameroon is associated with EH. Data were analyzed from 60 patients and 50 healthy controls in order to access the risk factors of $\mathrm{EH}$ in this ethnic group. Comparison of gene and allele frequency distributions between the two populations revealed that systolic and diastolic blood pressures, age, family history and lack of physical exercise were risk factors of EH in this ethnic group. Comparison of means of age, systolic and diastolic blood pressures as well as the proportions of individuals with a family history of EH and lack of physical exercise were higher in the hypertensive than the normotensive group $(\mathrm{p}<$ 0.05). In addition, Comparison of genotype and allele frequencies between the two populations did not reveal statistically significant differences ( $p>0.05$ ). Moreover, analyses of relationship between ACE I/D gene variants and EH did not reveal any association $(p>0.05)$. Consistently, the two groups also did not present with differences in I and D allele distribution $(\mathrm{p}>0.05)$. These results suggest that EH is not associated with ACE I/D polymorphism.
\end{abstract}

(C) 2016 International Formulae Group. All rights reserved.

Keywords: ACE, Gene polymorphism, SWR, Cameroon. 


\section{INTRODUCTION}

Cardiovascular diseases (CVDs) are becoming a major health burden in developing countries including Cameroon (Kamadjeu et al., 2006; Dzudie et al., 2012, Gomina et al., 2012). Hypertension (HTN) is a major risk factor for CVDs including stroke and coronary heart disease. It is a multifactorial and polygenic disorder in which the interaction between several candidate genes and environmental factors play a critical role. This disease is becoming a worldwide public health problem and a leading cause of morbidity and mortality especially in developing countries, where studies project an increase by $60 \%$ by the year 2025 (Kearney et al., 2005; Hajjar et al., 2006).

A WHO 2012 report states that up to $50 \%$ of adults in many countries are estimated to have high blood pressure that remain undiagnosed. Previous surveys in Cameroon on HTN reported prevalence varying from $12 \%$ to $22 \%$ in those above 25 years (Cooper et al., 1997; Kearney et al., 2004; Mbanya et al., 1998). Based on the results of a crosssectional survey carried out in 2003, this prevalence of HTN was $25.6 \%$ in male and $23.1 \%$ in female (Kamadjeu et al., 2006). Most recent epidemiological study reported the prevalences of males and females in Cameroonian population were are $50.1 \%$ and $44.6 \%$ respectively (Dzudie et al., 2012).

This disease is known to be associated with both genetic and environmental factors. Environmental factors such as lack of physical exercise, excessive smoking, alcohol consumption, overweight and obesity are known to the risk factors involving increased blood pressure. Although the development of EH has been reported to be caused by both genetic and non-genetic risk factors (Whelton et al., 2002; Garcia et al., 2003), the underlying mechanisms are still not well understood. Numerous studies have been focused on the role of genetic variation of genes implicated in the renin-angiotensin system (RAS), particularly the angiotensinconverting enzyme (ACE) gene. ACE polymorphism is reported as a possible genetic determinant that could influence the development of EH. Association studies between this polymorphism and $\mathrm{EH}$ have been conducted in different countries and ethnicities. However, the results obtained according to different areas of studies are still contradictory. In Japan (Higaki et al., 2000) and India (Zarouk et al., 2012), DD genotype significantly increased risk of developing EH. Whereas no effect of the presence of DD genotype was observed in Dutch (Schidmt et al., 1993), Tunisian (Kabadou et al., 2013), and Indonesian (Rasyid et al., 2012) populations.

Due to the marked inconsistency in findings of the association of ACE polymorphism and EH in different ethnicities and geographical locations, establishment of this association in the Cameroonian population could reveal new insights on the control, prevention and management on the disease. Therefore, identification of these EHsusceptible genes is potentially useful to elucidate the complex genetic mechanisms of the disease. This would allow for earlier screening and diagnosis of high-risk individuals, preventing disease progression through early lifestyle changes and pharmacological treatment (Quenum et al., 2014) thus contributing to a reduction of complications and incidence of $\mathrm{EH}$

Cameroon is made up of 10 Regions with over 240 tribes distributed in three main ethnic groups: Bantu (Center, South, East, Southwest and Littoral regions), Semi-Bantu (North West and West regions) and Fulbes (Adamawa, Far North and North regions) (Achidi et al., 2012). The present study was undertaken to determine the association between ACE I/D gene polymorphism and $\mathrm{EH}$ among the Bantu ethnic population in Buea, South West Region of Cameroon. 


\section{MATERIALS AND METHODS}

\section{Study design}

This was a cross sectional populationbased study with participants randomly selected on a home-to-home basis. Ethical clearance and administrative authorization required for this investigation were obtained from the Cameroon Bioethics InitiativeEthical Review and Consultancy Committee (CAMBIN-ERCC), Yaounde-Cameroon and the South West Regional Delegation of Public Health respectively. Informed consent was obtained from all participants.

\section{Study population}

This study included $60 \mathrm{EH}$ patients (hypertensives) and 50 healthy controls (normotensives) selected from the population attending the Buea Health District area. The hypertensive group was comprised of unrelated individuals having been previously diagnosed with HTN and/or took antihypertensive drugs, having a blood pressure $\geq 140 / 90 \mathrm{mmHg}$, aged between 22 and 81 years inclusive.

Persons who had developed complications as a result of HTN, aged less than 22 or older than 81 , were excluded from the study. Unrelated subjects and without any history of HTN, diabetes and other immunosuppressive conditions were enrolled as normal control subjects. All participants were of the Bantu ethnic origin as well as their ancestors three generations back.

\section{Collection of demographic, anthropometric, biological and biochemical data}

A certified nurse used structured questionnaires for collection of both demographic data (age, sex, family history, alcohol consumption) and anthropometric data (height \& weight) (Knowles et al., 2007). The body mass index (BMI) was calculated according to Quetelet equation (Lacksmi et al., 2015). For acquisition of biological data two morning systolic (SBP) and diastolic (DBP) blood pressure measurements were taken using a sphygmomanometer (Omron health care, Illinois, USA) as described by Sharman et al., 2015. A third measurement was taken only when the difference between the two measurements was greater than 5 $\mathrm{mmHg}$, and the readings were averaged for analysis. A 5-min. relaxation period between measurements was maintained for all subjects.

For biochemical data, fasting blood sugar (FBS) was determined in $\mathrm{mg} / \mathrm{dl}$ glucose using OneTouch UltraMini strip ${ }^{\mathrm{TM}}$ and analyzer (Carlifornia, USA). Serum triglycerides (TGs) were determined by enzymatic colorimetric method using a commercially kit (ChronoLab, Barcelona, Spain) according to the manufacturer's instructions. Total cholesterol (TC) and high density lipoprotein cholesterol (HDL-C) were determined using a Kit (ChronoLab, Barcelona, Spain) according to the manufacturer's instructions. Serum LDL was calculated using the formula: LDL-C $=(\mathrm{TC})$ (HDL-C) - (TG/5) (NIH 2001).

\section{ACE gene I/D polymorphism}

Two millilitres of whole blood were collected by venipuncture from patients in EDTA-microtainer tubes and kept at $4{ }^{\circ} \mathrm{C}$ for less than 12 hours until DNA extraction. Genomic DNA was extracted from the whole blood by non-enzymatic salting out method as described by Sajja et al., 2014. The DNA extract was used directly for PCR or stored at$20^{\circ} \mathrm{C}$ to be used later for PCR

PCR amplification of the ACE gene was done using specific primers to ACE gene as described by Nakhjavani et al., 2007. The reaction was performed in $100 \mu \mathrm{L}$ PCR tubes with $5 \mu \mathrm{L}$ of $100 \mu \mathrm{M}$ of each primer (forward: 5'-CTG GAG ACC ACT CCC ATC CTT TCT-3' and reverse: 5'-GAT GTG GCC ATC ACA TTC GTC AGAT-3') in a final volume of $24 \mu \mathrm{L}$, containing $1.5 \mu \mathrm{L}$ genomic DNA $(0.2 \mu \mathrm{g})$ suspension and $12.5 \mu \mathrm{L}$ of PCR 
Master Mix (Sigma). All DNA samples were quantified by a spectrophotometer (Unico SpectroQuest Model SQ2800, USA) as described by the manufacturer. PCR was done with a pre-denaturation step at $94{ }^{\circ} \mathrm{C}$ for 1 min, then the DNA was amplified for 30 cycles with a denaturation step at $94{ }^{\circ} \mathrm{C}$ for 30 sec, annealing at $58{ }^{\circ} \mathrm{C}$ for $30 \mathrm{sec}$, and extension step at $72{ }^{\circ} \mathrm{C}$ for $1 \mathrm{~min}$ followed by a final extension step at $72{ }^{\circ} \mathrm{C}$ for $5 \mathrm{~min}$. PCR products were analyzed on $3 \%$ agarose gel.

Mistyping of the ID genotype for DD genotype due to preferential amplification of the D allele (190 bp) over the I allele (490 bp) was verified using a second set of insertion allele-specific primers ( primer: 5'-TCG GAC CAC AGC GCC CGC CAC TAC-3' and antisense primer: 5'- TCG CCA GCC CTC CCA TGC CCA TAA-3').

\section{RESULTS}

Clinical data from hypertensive and normotensive subjects

In total, 110 subjects were examined, 50 of them being normotensive, and 60 hypertensive. Anthropometric, biochemical and biological data were compared between hypertensive and normotensive subjects. Comparison of anthropometric data and proportions of life style parameters between normotensive and hypertensive subjects revealed that no significant differences were observed except for the lack of exercise and family history. The proportion of individuals that did not make exercise was significantly higher in the hypertensive than that of normotensive group $(p=0.011)$ The same results were obtained for family history $(\mathrm{p}=$ 0.018) (Table 1). In the same manner, biological and biochemical data comparison between the two groups showed that SBP and DBP were significantly higher in the hypertensive group than the normotensive $(p=0.0001$ in both cases) Analysis of the means of the clinical characteristics between hypertensive and normotensive group showed no statistical significant differences (RBS: $\mathrm{p}=$ 0.2882; TC: $\mathrm{p}=0.9450 ; \mathrm{TG}: \mathrm{p}=0.9761$; HDL-C: $p=0.9999$; and LDL-C: $p=0.8920$ ) (Table 2).

\section{Genotype and allele frequencies of ACE I/D gene polymorphisms}

To investigate the role of the ACE gene in the prediction of $\mathrm{EH}$, genotype and allele frequencies were compared between normotensive and hypertensive subjects. Following genotyping both normotensives and hypertensives, deletion polymorphism was characterized by a 190-bp fragment, while the presence of the insertion was observed as a 490-bp fragment. Whereas the II genotype was totally absent, the ID and DD genotypes were present in both study groups (Figure 1). Verification for mistyping of the DD genotype yielded a 335-bp fragment in the presence of the I-allele and no product for homozygote DD genotype (Data not shown).

\section{Association studies of ACE gene variants with risk factors of hypertension}

An association study was conducted between ACE gene variants and risk factors in the study populations. Analyses of results reveal that no statistically significant differences in ACE gene or allele frequencies existed between the normotensives and the hypertensives. Consistently, similar results were obtained when ACE gene and allele frequencies were compared between hypertensive subjects with high SBP or DBP with those of low SBP or DBP (Table 3). Similarly, there was neither association of ACE gene variants with gender and age group (Table 4) nor with life style risk factors of hypertension (Table 5). Merging the two populations into a single group did not reveal any association between genotype and risk factors of EH (Data not shown). 
Table 1: Characteristics and statistical comparison of anthropometric data and life style parameters between the hypertensive and normotensive subjects.

\begin{tabular}{|c|c|c|c|}
\hline Parameters & Hypertensives $(n=60)$ & Normotensives $(\mathrm{n}=50)$ & Test Statistics \\
\hline Sex (Male/Female) & $29 / 31$ & $28 / 22$ & $\chi^{2}=0.642 ; p=0.4230$ \\
\hline Age: Years & $51.47 \pm 12.66$ & $46.30 \pm 10.81$ & $\mathrm{p}=0.025 ; 95 \% \mathrm{CI}$ \\
\hline $\mathrm{BMI}\left(\mathrm{Kg} / \mathrm{m}^{2}\right)$ & $28.90 \pm 4.922$ & $27.73 \pm 4.362$ & $\mathrm{p}=0.3724$ \\
\hline Alcohol consumption & $46(76.67 \%)$ & $44(88 \%)$ & $\chi^{2}=0.125 ; \mathrm{p}=0.723$ \\
\hline Smoking & $6(10 \%)$ & $9(18 \%)$ & $\chi^{2}=1.482 ; p=0.223$ \\
\hline Lack of exercise & $27(45 \%)$ & $38(76 \%)$ & $\chi^{2}=6.392 ; \mathbf{p}=\mathbf{0 . 0 1 1} *$ \\
\hline Family History & $30(50 \%)$ & $13(26 \%)$ & $\chi^{2}=3.917 ; \mathbf{p}=\mathbf{0 . 0 4 7} *$ \\
\hline
\end{tabular}

Table 2: Characteristics and statistical comparison of and biological and biochemical data between the hypertensive and normotensive subjects.

\begin{tabular}{lcccc}
\hline Parameters & Reference range & Hypertensives $(\mathbf{n}=\mathbf{6 0})$ & Normotensives $(\mathbf{n}=50)$ & p value \\
\hline SBP $(\mathrm{mm} \mathrm{Hg})$ & $<140$ & $150.3 \pm 16.77$ & $117.9 \pm 11.35$ & $0.0001^{*}$ \\
DBP $(\mathrm{mm} \mathrm{Hg})$ & $<90$ & $97.02 \pm 9.092$ & $79.06 \pm 7.646$ & $0.0001^{*}$ \\
RBS $(\mathrm{mg} / \mathrm{dL})$ & $<200$ & $137.5 \pm 114.9$ & $124.6 \pm 34.79$ & 0.2882 \\
TC $(\mathrm{mg} / \mathrm{dL})$ & $<200$ & $218.0 \pm 93.14$ & $217.80 \pm 99.50$ & 0.9450 \\
TG $(\mathrm{mg} / \mathrm{dL})$ & $35-160$ & $113.9 \pm 95.19$ & $110.0 \pm 77.96$ & 0.9761 \\
HDL-C $(\mathrm{mg} / \mathrm{dL})$ & $>65$ & $68.32 \pm 25.05$ & $68.32 \pm 23.43$ & 0.9999 \\
LDL-C $(\mathrm{mg} / \mathrm{dL})$ & $<150$ & $115.5 \pm 96.74$ & $120.8 \pm 98.78$ & 0.8920 \\
\hline
\end{tabular}

All values (means) were compared using the student-t test at $95 \% \mathrm{CI}$; * indicates statistical significance

Table 3: Association of ACE gene variants with biological risk factors of hypertension.

\begin{tabular}{|c|c|c|c|c|c|c|c|c|}
\hline & & & & \multicolumn{3}{|c|}{ Genotype } & \multicolumn{2}{|c|}{ Allele } \\
\hline & & & & II & ID & DD & $\mathbf{I}$ & D \\
\hline \multirow[t]{5}{*}{ Status } & \multirow{2}{*}{\multicolumn{2}{|c|}{ Hypertensives }} & $n=60$ & 00 & 35 & 25 & 35 & 85 \\
\hline & & & $\%$ & 00 & 58.3 & 41.7 & 29.2 & 70.8 \\
\hline & \multirow{3}{*}{\multicolumn{2}{|c|}{ Normotensives }} & $\mathbf{n}=\mathbf{5 0}$ & 00 & 33 & 17 & 33 & 67 \\
\hline & & & $\%$ & 00 & 66 & 34 & 33 & 67 \\
\hline & & & & \multicolumn{3}{|c|}{$\chi 2=0.679 ; p=0.4099$} & \multicolumn{2}{|c|}{$\chi^{2}=0.375 ; p=0.540$} \\
\hline \multirow{3}{*}{\multicolumn{2}{|c|}{ DBP in hypertensives }} & $>90 \mathrm{mmHg}$ & $n=45$ & 00 & 24 & 21 & 24 & 66 \\
\hline & & $\leq 90 \mathrm{mmHg}$ & $\mathrm{n}=\mathbf{1 5}$ & 00 & 11 & 4 & 11 & 19 \\
\hline & & & & \multicolumn{3}{|c|}{$\chi^{2}=1.851 ; \quad P=0.173$} & \multicolumn{2}{|c|}{$\chi^{2}=1.089 ; P=0.296$} \\
\hline \multirow{3}{*}{\multicolumn{2}{|c|}{ SBP in Hypertensives }} & $>140 \mathrm{mmHg}$ & $n=46$ & 00 & 27 & 19 & 27 & 65 \\
\hline & & $\leq 140 \mathrm{mmHg}$ & $n=14$ & 00 & 8 & 6 & & 20 \\
\hline & & & & \multicolumn{3}{|c|}{$\chi^{2}=0.010 ; P=0.917$} & \multicolumn{2}{|c|}{$\chi^{2}=0.006 ; \quad P=0.936$} \\
\hline
\end{tabular}

All values were compared using the Chi square test 
Table 4: Association of ACE gene variants with anthropometric risk factors of hypertension.

\begin{tabular}{|c|c|c|c|c|c|c|c|c|}
\hline & & & & & Gen & & & \\
\hline & & & & II & ID & DD & I & D \\
\hline & Males & Normotensive & $\mathrm{n}=28$ & 00 & 16 & 12 & 16 & 40 \\
\hline Gender & & Hypertensive & $\mathrm{n}=29$ & 00 & 12 & 17 & 12 & 46 \\
\hline & & & & $\chi^{2}=$ & 416; & 234 & $\chi^{2}=$ & $=0.328$ \\
\hline & Females & Normotensive & $\mathrm{n}=22$ & 00 & 17 & 4 & 17 & 25 \\
\hline & & Hypertensive & $\mathrm{n}=31$ & 00 & 23 & 8 & 23 & 39 \\
\hline & & & & & 322; & 570 & $\chi^{2}=$ & $=0.728$ \\
\hline & 22-34 & Normotensive & $\mathrm{n}=6$ & 00 & 03 & 03 & 03 & 09 \\
\hline & & Hypertensive & $\mathrm{n}=5$ & 00 & 04 & 01 & 04 & 06 \\
\hline & & & & & 061 ; & & & $=0.452$ \\
\hline & $35-49$ & Normotensive & $\mathrm{n}=26$ & 00 & 19 & 07 & 19 & 33 \\
\hline Age & & Hypertensive & $\mathrm{n}=19$ & 00 & 12 & 07 & 12 & 26 \\
\hline group & & & & & 504; & & $\chi^{2}=$ & $=0.624$ \\
\hline & $50-64$ & Normotensive & $\mathrm{n}=15$ & 00 & 08 & 07 & 08 & 22 \\
\hline & & Hypertensive & $\mathrm{n}=27$ & 00 & 15 & 12 & 15 & 39 \\
\hline & & & & & 019 ; & & $\chi^{2}=$ & $=0.912$ \\
\hline & $65-81$ & Normotensive & $\mathrm{n}=3$ & 00 & & 00 & 03 & 03 \\
\hline & & Hypertensive & $\mathrm{n}=9$ & 00 & & 05 & 04 & 14 \\
\hline & & & & $\chi^{2}=$ & 857; & & $\chi^{2}=$ & $=0.194$ \\
\hline
\end{tabular}

Chi Square test was used to analyse data.

Table 5: Association of ACE gene variants with family history and lack of exercise.

\begin{tabular}{|c|c|c|c|c|c|c|c|c|}
\hline & & & & \multicolumn{3}{|c|}{ Genotype } & \multicolumn{2}{|c|}{ Allele } \\
\hline & & & & II & ID & DD & I & D \\
\hline \multirow{6}{*}{$\begin{array}{l}\text { Lack of } \\
\text { Exercise }\end{array}$} & Yes & Normotensive & $\mathrm{n}=\mathbf{3 8}$ & 00 & 25 & 13 & 25 & 51 \\
\hline & & Hypertensive & $\mathbf{n}=\mathbf{2 7}$ & 00 & 15 & 12 & 15 & 39 \\
\hline & & & & \multicolumn{3}{|c|}{$\chi^{2}=0.69 ; P=0.403$} & \multicolumn{2}{|c|}{$\chi^{2}=0.388 ; P=0.533$} \\
\hline & No & Normotensive & $\mathrm{n}=12$ & 00 & 08 & 04 & 08 & 16 \\
\hline & & Hypertensive & $\mathbf{n}=\mathbf{3 3}$ & 00 & 20 & 13 & 20 & 46 \\
\hline & & & & \multicolumn{3}{|c|}{$\chi^{2}=0.137 ; P=0.710$} & \multicolumn{2}{|c|}{$\chi^{2}=0.075 ; P=0.783$} \\
\hline \multirow{6}{*}{$\begin{array}{l}\text { Family } \\
\text { History }\end{array}$} & Yes & Normotensive & $n=15$ & 00 & 10 & 05 & 10 & 20 \\
\hline & & Hypertensive & $\mathrm{n}=\mathbf{3 3}$ & 00 & 18 & 15 & 18 & 48 \\
\hline & & & & \multicolumn{3}{|c|}{$\chi^{2}=0.623 ; P=0.429$} & \multicolumn{2}{|c|}{$\chi^{2}=0.366 ; P=0.544$} \\
\hline & No & Normotensive & $\mathbf{n}=35$ & 00 & 23 & 12 & 23 & 47 \\
\hline & & Hypertensive & $\mathrm{n}=\mathbf{2 7}$ & 00 & 10 & 17 & 10 & 44 \\
\hline & & & & \multicolumn{3}{|c|}{$\chi^{2}=5.035 ; P=0.024$} & \multicolumn{2}{|c|}{$\chi^{2}=3.209 ; P=0.073$} \\
\hline
\end{tabular}




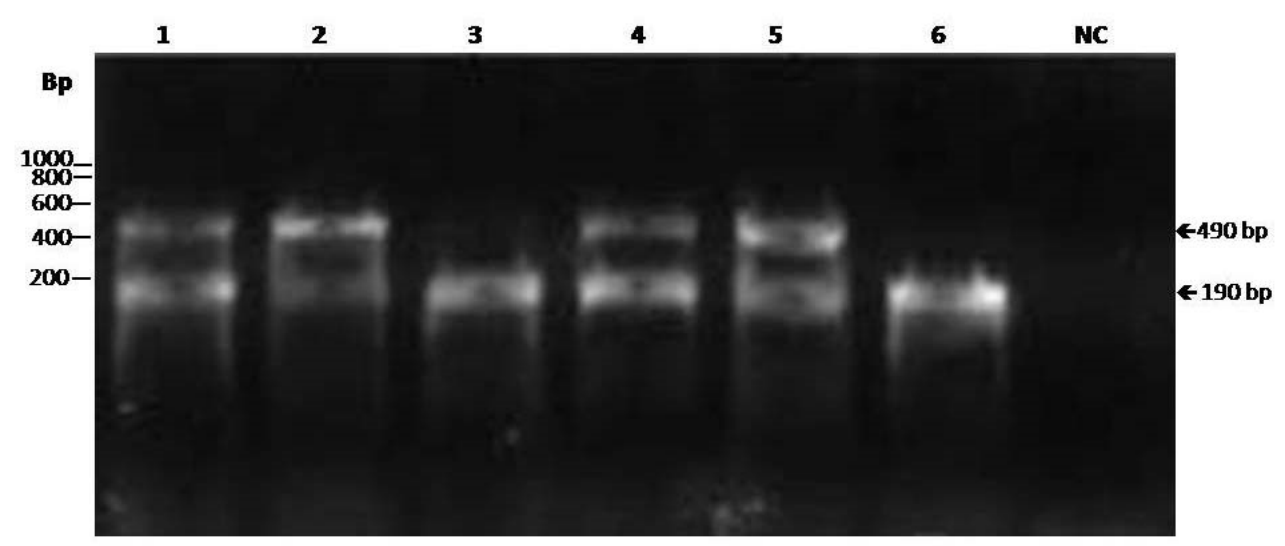

Figure 1: Typical agarose gel electrophoregram of ACE gene polymorphism. Lanes 1, 2, 4 \& 5: ID genotype; Lanes 3 \& 6: DD genotype; Lane NC: negative control. Arrows indicate the 490 and the 190 bp fragments of the I and $\mathrm{D}$ alleles respectively.

\section{DISCUSSION}

The present study was aimed at investigating the association of ACE I/D polymorphism with $\mathrm{EH}$ among the Bantu ethnic population in Buea, SWR of Cameroon. The identification of this polymorphism in this subset of the Cameroonian population as a health risk factor will help people predisposed to $\mathrm{EH}$ to take adequate health decisions in order to prevent the disease and its complications.

A subpopulation analysis according to potential risk factors of $\mathrm{EH}$ revealed that age SBP, DBP, lack of exercise and family history were risk factors in the Bantu ethnic group while gender, BMI, lipid profile, alcoholism and smoking were not (Tables $1 \& 2$ ). EH was more prevalent in the elderly than young people. This was in accordance with previous studies in different towns of Cameroon (Kamadjeu et al., 2006; Dzudie et al., 2012). Increase in age is thought to increase blood pressure because as the arteries become hardened, there is increased resistance to blood flow (Roger et al., 2011).

The high SBP and DBP in hypertensive patients were naturally expected. These results reveal that SBP and DBP are risk factors for $\mathrm{EH}$ in the Bantu ethnic population of SWR Cameroon. In recent years, considerable evidence has suggested that changes in vascular endothelial function may cause the increase in vascular tone, in addition to sympathetic activity and increased circulating levels of angiotensin II (Franklin et al., 2011).

The proportion of individuals who did not make exercise or with a family history of EH was statistically different between the hypertensive patients and control population, suggesting that genetic and lifestyle environmental factors do influence the ability to develop this disease in the Bantu ethnic group. These observations are in line with earlier reports (Bhavani et al., 2004), thereby providing evidence that heritable factors in combination with a number of recognized environmental risk factors are important determinants of the pathogenesis of $\mathrm{EH}$ in this study population.

Analysis of association of identified risk factors of hypertension with ACE genotypes did not reveal any differences in genotype and allele prevalence between the hypertensive and normotensive populations (Figures 3, 4 and 5). These data suggests that there is no association between the ACE I/D polymorphism and EH. Consistently, merging the two groups of normotensives and hypertensives into a single population did not reveal any association between ACE gene variants and risk factors of $\mathrm{EH}$ (Data not shown). Similar results have been reported in the Dutch (Schidmt et al., 1993), Tunisian (Kabadou et al., 2013), and Indonesian (Rasyid et al., 2012) populations and has been attributed to ethnic background. 
The present study clearly demonstrates that the ACE I/D gene variants do not predispose Cameroonians of the Bantu ethnic group to $\mathrm{EH}$.

\section{ACKNOWLEDGEMENTS}

This research work received financial support from the Cameroon Ministry of Higher Education in the form of research modernization allowance as well as from the 'Academie de Recherche et d'Enseignement Superieur - Commission de la Cooperation au Development' (ARES-CCD), Belgium in the form of laboratory equipment to the Molecular and Cell Biology Laboratory of the Biotechnology Unit.

\section{COMPETING INTERESTS}

The authors declare that they have no competing interests.

\section{AUTHORS CONTRIBUTIONS}

SMG was the principal investigator; he designed the project and did the genotype determination. MNT did the DNA extraction, Lipid profile determination and data analyses. JIMM did the Field data collection and glycaemic level determination.

\section{REFERENCES}

Achidi EA, Apinjoh TO, Anchang-Kimbi JK, Mugri RN, Ngwai AN, Yafi CN. 2012. Severe and uncomplicated falciparum malaria in children from three regions and three ethnic groups in Cameroon: prospective study. Malaria Journal, 11: 215.

Assoumanou MG, Dovonou MC, Ngome M R, Akpona SA. 2012. Prévalence du syndrome métabolique chez les sujets hypertendus adultes dans les formations sanitaires de Parakou (Bénin). Int. J. Biol. Chem. Sci., 6(4): 1419-1427

Bhavani BA, Padma T, Shastry BKS, Reddy, NKS. 2004. Gender specific association on insertion/deletion polymorphism of the human angiotensin converting enzyme gene with essential hypertension. International Journal of Human Genetics, 4: 207-213.
Cooper R, Rotimi C, Ataman S, McGee D, Osotimehin B, Kadiri S. 1997. The prevalence of hypertension in seven populations of West African origin. American Journal Public Health, 87: 160-168.

Dzudie A, Kengne AP, Muna WF, Ba H, Menanga A, Kouam CK, 2012. Prevalence, awareness, treatment and control of hypertension in a self-selected sub-Saharan African urban population: a cross-sectional study. British Medical Journal, 2 (4): e001217.

Franklin SS, Gustin W, Wong ND. 2009. Hemodynamic patterns of age-related changes in blood pressure: the Framingham Heart Study. Circulation, 96: 308-315.

Garcia EA, Newhouse S, Caulfield MJ, Monroe PJ. 2003. Genes and hypertension. Current Pharmaceutical Design, 9: 1679-1689.

Hajjar I, Kotchen JM, Kotchen TA. 2006. Hypertension: trends in prevalence, incidence, and control. Annual Review of Public Health, 27: 465-490.

Higaki J, Baba S, Katsuya T, Sato N, Ishikawa K, Mannami T, Ogata J, Ogihara T. 2000. Deletion allele of angiotensin-converting enzyme gene increase risk of essential hypertension in Japanese men. The Suita study. Circulation, 101: 2060-2065.

Kabadou IA, Soualmia H, Jemaa R, Feki M, Kallel A. 2013. G protein beta3 subunit gene $\mathrm{C} 825 \mathrm{~T}$ and angiotensin converting enzyme gene insertion/deletion polymorphisms in hypertensive Tunisian population. Clinical Laboratory, 59(12): 85-92.

Kamadjeu RM, Edwards R, Atanga JS, Unwin N, Kiawi EC, Mbanya JC. 2006. Prevalence, awareness and management of hypertension in Cameroon: findings of the 2003 Cameroon Burden of Diabetes Baseline Survey. Journal of Human Hypertension, 20: 91-92.

Kearney PM, Whelton M, Reynolds K, Muntner P, Whelton PK, He J. 2005. Global burden of hypertension: analysis of worldwide data. Lancet, 365: 217-223. 
Kearney P M, Whelton M, Reynolds K, Whelton PK, He J. 2004. Worldwide prevalence of hypertension: a systematic review. Journal of Hypertension, 22: 1119.

Knowles KM, Paiva LL, Sanchez SE, Revilla L, Lopez T, Yasuda MB, Yanez ND, Gelaye B, Williams MA. 2005. Waist circumference, body mass index, and other measures of adiposity in predicting cardiovascular disease risk factors among Peruvian adults. International Journal of Hypertension.

Lacksmi Y, Vasundara DB. 2015. A Study of Body Mass Index among Medical Students in a Tertiary Care Teaching Hospital. Journal of Dental Medical Science, 14: 14-17.

Mbanya JC, Minkoulou EM, Salah JN, Balkau B. 1998. The prevalence of hypertension in rural and urban Cameroon. International Journal of Epidemiology, 27: 181-185.

Nakhjavani M, Esfahanian F, Jahanshahi A, Esteghamati A, Nikzamir A R, Rashidi A, Zahraei M. 2007. The relationship between the insertion/deletion polymorphism of the ACE gene and hypertension in Iranian patients with type 2 diabetes. Nephrolpgy Dialysis Transplantation, 22(9): 2549-2553.

National Heart, Lung, and Blood Institute. (2001). Third Report of the National Cholesterol Education Program (NCEP) Expert Panel. Detection, evaluation and treatment of high blood cholesterol in adults (Adult Treatment Panel III) NIH Publication No. 013670.

Quenum CT, Ahissou H, Gouthon P, Laleye A. 2014. Etude de l'activité antihypertensiv e d'une association de plantes (Schrankia leptocarpa, Garcinia kola et Ocimum a mericanum) chez le rat Wistar. Int. J. Biol. Chem. Sci., 8(6): 2685-2695. DOI : http://dx.doi.org/10.4314/ijbcs.v8i6.28

Rasyid H, Bakri S, Yusuf I. 2012. Angiotensin-converting enzyme gene polymorphisms, blood pressure and pulse pressure in subjects with essential hypertension in a South Sulawesi Indonesian population. Acta Medica Indonesiana, 44 (4): 280-283.

Roger VL, Go AS, Lloyd-Jones DM, Adams RJ, Berry JD, Brown TM, Carnethon MR, Dai S, de Simone G, Ford ES, Fox CS. 2011. Heart disease and stroke statistics2011 update a report from the American Heart Association. Circulation, 123(4): e18-209.

Sajja S, Nandal DH, Suresk K, Ambadasu B, Rahul K. 2014. Genomic DNA isolation from human whole blood samples by non-enzymatic salting out method. International Journal of Pharmacy and Pharmaceutical Sciences, 6(4): 198-199.

Schmidt S, Van Hooft IM, Grobbee DE, Ganten D, Ritz E. 1993. Polymorphism of the angiotensin I converting enzyme gene is apparently not related to high blood pressure: Dutch Hypertension and Offspring Study. Journal of Hypertension, 11: $345-348$

Sharman JE, Howes FS, Head GA, McGrath BP, Stowasser M, Schlaich M. 2015. Home blood pressure monitoring: Australian expert consensus statement. Journal of hypertension, 33(9): 1721.

Whelton PK, He J, Appel LJ, Cutler JA, Havas S, Kotchen TA. 2002. Primary prevention of hypertension: clinical and public health advisory from The National High Blood Pressure Education Program. JAMA, 288: 1882-1888.

World Health Organization. 2012. New data highlight increases in hypertension, diabetes incidence. The World health statistics 2012 report, Geneva, Switzerland. http://www.who.int/ whr/2012/.

Zarouk WA, Hussein IR, Esmaeil NN, Raslan HM, Reheim HA. 2012. Association of angiotensin converting enzyme gene (I/D) polymorphism with hypertension and type 2 diabetes. Bratislavske Lekarske Lisky, 113(1): 14-18. 